\title{
HUKUM ISLAM DAN HUKUM POSITIF: PERBEDAAN, HUBUNGAN, DAN PANDANGAN ULAMA
}

\author{
Alda Kartika Yudha \\ Program Pascasarjana Universitas Islam Indonesia \\ Jalan Cik Ditiro No. 1 Yogyakarta \\ +628121545453/al yudha@yahoo.co.id
}

\begin{abstract}
History tells us that the struggle to make sharia law as the basic rule of state is nothing new. From the era of Șahābah until now, there are many organizations and movements try to do so in every corner of this world. The figures like Hasan al-Banna, Sayyid Quțb, al-Maudūdi, Abdul Qodir 'Audah, Taqiyuddin an-Nabhani and Abu Bakr Ba'āsyir are the examples who try make sharia law as the basic rule of state. But in reality, Islamic scholars themselves have their own opinion regarding this subject, weather we have to make sharia law as the basis of the country or not. Some scholars say those who are not using sharia law are kafir (non believer), but others say Allah allows us to use any rules that fit (as long as not contradict with Islamic value). Indonesia itself is a country that has a lot of diversity in tribe, language, even religion, so the idea of an Islamic state will face many obstacles. In the other hand, Pancasila as Indonesia's ideology seems to be fit and it was a smart choice chosen by our founding fathers at the time of declaration of independence to make Indonesians united, and additionally still it compromize the idea of Islam as raḥmatan lil 'âlamin.
\end{abstract}

Keywords: Sharia Law; Positive Law; State

\begin{abstract}
Abstrak
Sejarah memberitahukan kita bahwa perjuangan menjadikan syariat Islam sebagai dasar negara, bukanlah hal yang baru. Sejak zaman sahabat hingga sekarang, sudah banyak pergerakan, organisasi, dan paham yang ingin menjadikan syariat Islam sebagai hukum positif yang berlaku di segala penjuru dunia. Tokoh-tokoh seperti Hasan al-Banna, Sayyid Quțb, al-Maudūdi, Abdul Qodir 'Audah, Taqiyuddin an-Nabhani and Abu Bakr Ba'āsyir, merupakan segelintir tokoh yang mencoba menjadikan Syariat Islam sebagai hukum positif. Akan tetapi, pada kenyataannya, ulama berbeda pendapat mengenai keharusan berhukum dengan syariat Islam ini. Sebagian mengatakan mereka yang tak berhukum dengan syariat Islam maka termasuk orang kafir, dan sebagian yang lain membolehkannya. Indonesia sendiri merupakan negara majemuk yang memiliki banyak keberagaman baik suku, bahasa bahkan agama, sehingga cita-cita untuk menjadikan hukum Islam sebagai hukum positif akan mengalami banyak halangan. Ideologi Pancasila bisa dikatakan merupakan kesepakatan cerdas para pendahulu kala itu, karena dengan hal ini,
\end{abstract}


Indonesia terbebas dari perpecahan, sekaligus tetap bisa mewujudkan cita-cita Islam sebagai raḥmatan lil 'ālamīn.

Kata Kunci: Hukum Islam; Hukum Positif, Negara

\section{A. PENDAHULUAN}

Meminjam istilah Haedar Nashir (2013: 16), pejuang Islam syariat (para pejuang yang berusaha memperjuangkan hukum Islam sebagai hukum positif) kian hari kian banyak dan semakin gigih. Jika dilihat dari kacamata sejarah, sebenarnya pejuang Islam syariat ini bukanlah hal yang baru. Sejak zaman sahabat hingga dewasa ini, sudah banyak pergerakan, organisasi, dan paham yang ingin menjadikan syariat Islam sebagai hukum positif yang berlaku disegala penjuru dunia. Tokohtokoh seperti Ḥasan al-Banna, Sayyid Quțb, al-Maudūdi, Abdul Qodir 'Audah, Taqiyuddin an-Nabhani and Abu Bakr Ba'āsyir, merupakan segelintir tokoh dari dulu hingga sekarang yang mencoba penegakan Syariat Islam sebagai hukum Negara.

Semangat perjuangan mereka, tak lain dimulai dengan doktrin bahwa Islam itu adalah agama yang mengatur segala aspek kehidupan kita, tak terkecuali dalam perihal berhukum dan bernegara. Paham yang lebih dikenal dengan paham Islam integral ini dalam beberapa kasus bahkan sampai kepada titik ekstrim dengan mengatakan bahwa orang yang tidak mau berhukum dengan hukum Allah adalah orang-orang kafir, dan hukum positif yang digunakan oleh pemerintah sekarang (yang bukan dari syariat Islam) adalah țāghūt. Meskipun begitu, banyak sekali bantahan terhadap pendapat ini dengan banyaknya ulama muslim yang berpendapat sebaliknya. Dalam pandangan mereka soal bertata-negara itu adalah urusan duniawiyah yang masuk ke dalam golongan hadis "antum a'lamu bi umūri dunyākum" (kamu lebih paham degan perkara duniamu).

Perdebatan seperti di atas ternyata muncul kembali dewasa ini. Bahkan terkait hal ini pemerintah mengeluarkan Perppu Ormas No 2 tahun 2017 yang kemudian disahkan oleh DPR menjadi UU pada 24 Oktober 2017. Hal ini membuat gaduh masyarakat Indonesia dengan alasan pemerintah dianggap otoriter karena dianggap memberikan hak kepada dirinya sendiri untuk membubarkan ormas yang dianggap terlarang tanpa adanya proses pengadilan. Terlepas daripada itu, pemahaman mengenai pemerintah yang tidak menggunakan Syariat Islam adalah pemerintah yang țāghūt, kafir, serta hukum positif harus diganti dengan hukum Islam, yang merebak akhir-akhir ini harus ditanggapi dengan cermat dan tidak dibiarkan bergitu saja. Semua pihak terutama akademisi (ilmuan Islam), harus mampu menjelaskan kaitan antara negara dan agama sehingga pemahaman ini nantinya tidak menjadi konflik yang melebar yang bisa berujung pada perpecahan dan disintegritas bangsa. Artikel ini setidaknya ingin memberikan sumbangsih untuk mengingatkan kembali tentang keterkaitan agama dan negara serta hukum menggunakan hukum positif (yang bukan bersumber pada syariat) dalam padangan 
Islam yang nantinya juga akan menjelaskan bagaimana posisi Pancasila sebagai dasar negara Indonesia ditinjau dari sudut pandang Islam.

\section{B. PEMBAHASAN}

\section{Hukum Islam}

Abdul Wahab Khalaf mengartikan hukum Islam sebagai perintah (doktrin) dari Allah Swt., yang berkaitan dengan perbuatan orang-orang yang sudah mukallaf (orang yang sudah dikenai beban syariat), dalam bentuk perintah (mengerjakan atau meninggalkan suatu perbuatan), perizinan (boleh memilih), atau penetapan.

Contoh bentuk perintah untuk mengerjakan sesuatu adalah Surat al-Maidah ayat 1:

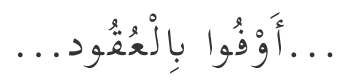

Artinya: “...tunaikanlah akad...”.

Contoh dari bentuk perizinan (boleh memilih) adalah Surat al-Baqarah ayat 229:

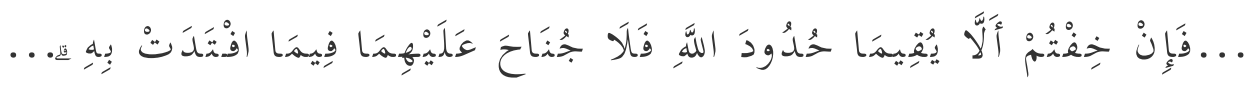

Artinya: “...dan jika kamu (wali) takut bahwa keduanya tidak bisa menegakkan aturan Allah, maka tidak ada dosa bagi kalian berdua atas bayaran yang (harus) diberikan oleh istri untuk menebus dirinya...". Ayat ini menjelaskan bentuk perizinan (pilihan) bagi suami untuk mengambil bayaran sebagai ganti talaknya kepada istrinya.

Sedangkan contoh dalam bentuk penetapan adalah hadis nabi yang berbunyi:

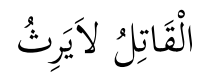

Artinya: "Tidak ada warisan bagi pembunuh (pewaris)". Di sini perintah Allah berkaitan dengan penetapan bagi ahli waris yang membunuh pewarisnya untuk tidak mendapatkan waris disebabkan perbuatannya (Khalaf, 2003: 91).

\section{Keistimewaan Hukum Islam terhadap Hukum Positif}

Dalam pandangan penegak Islam syariat, hukum Islam adalah hukum yang wajib ditegakan jika ingin tercapai keadilan sosial bagi seluruh rakyat baik di Indonesia maupun dunia. Hal ini dikarenakan hukum Islam mempunyai banyak keistimewaan dibandinkann dengan hukum positif yang diterapkan oleh manusia. Keistimewaan ini dapat dirinci sebagai berikut ('Audah, 2016: 11-20):

a. Hukum positif tidak memiliki keadilan hakiki karena dibuat oleh manusia dengan hawa nafsu dan kepentingan, sedangkan hukum Allah memiliki keadilan hakiki karena berasal dari yang Maha Adil. 
b. Hukum manusia hanya berdasarkan pertimbangan kekinian dan berdasar pengalaman, karena manusia tidak dapat mengetahui msa depan.

c. Hukum manusia memiliki prinsip yang terbatas yang teorinya baru muncul sekitar abad 19. Berbeda dengan hukum Islam yang sudah ada sejak zaman rasul yang sudah sempuna dan masalahah disegala ruang dan waktu.

d. Hukum positif hanya mengatur hubungan antar manusia. Hukum yang hanya mengandalkan aspek hukuman sering membuat penjahat untuk mencari celah pembenaran atas perilaku buruk mereka demi terbebas dari jerat hukum. Sedangkan dalam hukum Islam, aspek keridhoan Allah dan takut akan murkaNya menjadi faktor utama ketaatan.

e. Hukum positif mengabaikan aspek akhlak dan menganggap pelanggaran hukum hanya sebatas yang membahayakan individu dan masyarakat. Contoh: Hukum zina tidak di sanksi jika tidak ada paksaan dari satu pihak.

f. Hukum mencerminkan pembuatnya, ketika pembuatnya adalah manusia, maka hal ini harus dipahami bahwa manusia penuh dengan kukurangan meskipun ada kelebihannya. Sedangkan hukum Islam mencerminkan kesempurnaan dan keagungan pembuatnya.

g. Hukum positif memiliki kaedah yang bersifat temporal, dan hukum Islam bersifat tidak temporal. Hal ini dikarenakan kaedah dalam hukum Islam bersifat elastis dan umum dan juga berasal dari nash Islam yangbersifat tinggi dan mulia.

\section{Hukum Positif}

Hukum positif atau juga sering disebut sebagai ius constitutum, memiliki arti sebagai hukum yang sudah ditetapkan dan berlaku sekarang di suatu tempat atau Negara (Mertokusumo, 2007: 127-128). Indonesia dengan sistem civil law-nya menggunakan perundang-undangan, kebiasaan dan yurisprudensi sebagai sumber hukum (Marzuki, 2014: 258). Oleh karena itu bisa dikatakan agama, adat dan norma kesusilaan juga menjadi bagian dari hukum di Indonesia. Meskipun begitu, jika melihat di negara Indonesia, sumber hukum yang berlaku berdasarkan TAP MPR No. III/ MPR/2000 adalah Pancasila, sedangkan urut-urutan peraturan perundangundangannya adalah (Marzuki, 2014: 85-86):

a. UUD 1945 yang telah diamandemen sebanyak empat kali sejak 19 Oktober 1999

b. Ketetapan MPR

c. UU yang dibuat DPR bersama Presiden untuk melaksanakan UUD 1945 dan TAP MPR

d. Peraturan Pemerintah Pengganti Undang-Undang

e. Keputusan Presiden

f. Peraturan Daerah 


\section{Hubungan Antara Agama dan negara}

Dalam diskursus ini, setidaknya sejarah mencatat ada tiga model hubungan yang dijalin antara negara dan agama. Model relasi antara agama dan negara ini adalah paradigma integralistik, simbolik, dan sekularistik (Esnawi, 2013: 24-38).

\section{a. Paradigma Integralistik (Integrated Paradigm)}

Dalam pemikiran ini, agama dan negara bisa dikatakan menyatu. Agama masuk ke ranah politik dan negara, sedangkan negara juga menjadi lembaga politik dan keagamaan. Pemerintahan sebuah negara diselenggarakan atas dasar Kedaulatan Ilahi (Divine Sovereignity) dengan kekuasaan negara tertinggi berada ditangan Tuhan (atau lebih tepatnya tafsir manusia terhadap kalam Tuhan). Beberapa tokoh yang setuju dengan paradigma seperti ini adalah Sayyid Quțb (1906-1966), Abu al-'Ala al-Maudūdi (1903-1979), dan juga golongan Syiah yang menggunakan model Imamah (kepemimpinan para imam) yang juga bersifat teokrasi. Hal yang semisal juga tampak terlihat di Negara Vatikan yang menjadikan Paus sebagai pemimpin Negara sekaligus agama.

\section{b. Simbolistik (Symbiotic Paradigm)}

Pemikiran ini menjelaskan bahwa agama dan negara berhubungan secara simbiotik, yaitu hubungan timbal balik dan saling memerlukan. Dalam pandangan paradigma ini, agama dinilai sebagai seumber legitimasi atas realitas politik, sedangkan negara dinilai sebagai alat untuk menegakan syariah. Dalam hal ini, pemegang kekuasaan negara tidaklah harus pemegang otoritas keagamaan, karena yang terpenting dalam model ini adalah hubungan untuk saling mendukung satu sama lain. Model ini sangat berbeda dengan teokrasi (di mana kepala negara dan pertanggungjawabannya adalah kepada Tuhan), karena kepala negara ditentukan dan bertanggungjawab kepada rakyat serta tidak disandarkan pada mandat yang diberikan Tuhan. Boleh dikatakan bahwa sistem ini besumber pada kedaulatan rakyat, atau dikenal dengan konsep demokrasi. Beberapa tokoh Islam yang sepakat dengan sistem ini adalah al-Mawardi seorang pemikir politik pengarang kitab alahkām al-Sulțāniyah, al-Ghazali, serta Ibnu Taimiyah.

\section{c. Sekularistik (Secularistic Paradigm)}

Paradigma ini memiliki arti bahwa agama dan negara itu harus terpisah. Beberapa pemikir Islam yang setuju dengan konsep ini adalah Ali Abd al-Raziq (1888-1966) dan juga Thaha Husein (1889-1973). Menurut mereka Islam tidak mempunyai kaitan dengan sistem pemerintahan. Mereka menyatakan bahwa sistem kekhalifahan yang ada dalam sejarah Islam pada dasarnya tidak mempunyai dasa baik dari al-Quran maupun Sunnah nabi. Menurut mereka nabi tidak mendirikan Negara Madinah dan juga bukan kepala Negara, nabi adalah pemimpin dalam bidang agama. Islam dalam hal ini, tidak memerintahkan suatu sistem tertentu dan membebaskan kita untuk memilih sistem pemerintahan yang sesuai dengan politik, sosial, budaya di zaman masing-masing. Dalam pandangan mereka pembentukan dasar Negara adalah atas dasar manfaat-manfaat amaliah dan bukan atas dasar agama. 
Berdasar pengelompokan hubungan negara dan agama di atas, penulis lebih cenderung dengan hubungan yang kedua, tanpa menolak paradigma pertama, dan tidak setuju dengan paradigma ketiga. Hubungan simbiotik antara negara dan agama, khususnya dalam konteks ke-Indonesiaan lebih bisa diterima dan memiliki maslahat yang banyak.

Selama negara tidak melanggar prinsip-prinsip syariah dalam perjalanannya, maka sudah selayaknya kita mendukung perjuangan negara tersebut. Terlebih, sebenarnya sistem pemerintahan itu merupakan perkara duniawi yang kita lebih tahu di dalamnya (sebagaimana hadis "kamu lebih tahu tentang urusan duniamu"), sedangkan yang wajib dan menjadi tujuannya adalah tegaknya keadilan dan keamanan bagi seluruh bangsa. Dalam hal ini, dirasa cukup dengan menjadikan substansi dan pinsip-prinsip Islam (tidak perlu seutuhnya dinamakan hukum Islam) untuk masuk dalam sistem hukum negara. Dan justru ketika terbentuk negara Islam akan tetapi kita (sebagai muslim) tidak bisa menunjukan Islam raḥmatan lil 'ālamīn, hanya akan mencederai Islam itu sendiri tanpa kita sadari, sebagaimana banyak terjadi di negara Islam dewasa ini.

\section{Pandangan Ulama tentang Hukum Positif dan Hukum Islam}

Cendekiawan muslim berbeda pendapat tentang penggunaan hukum posisif yang sekarang marak di berbagai negara termasuk negara dengan penduduk muslim. Kelompok pertama mengatakan bahwa sebuah negara wajib hukumnya menggunakan hukum Islam sebagai hukum positif. Mereka yang tidak menggunakan hukum Islam adalah golongan orang-orang yang bermaksiat kepada Allah, bahkan kafir kepadaNya. Kelompok kedua mengatakan bahwa hukum positif yang ada (meskipun bukan hukum Islam) adalah sah digunakan dan hal tersebut tidak termasuk maksiat kepada Allah apalagi kafir dan keluar dari agama Islam. Adapun penjelasan lebih rincinya adalah sebagai berikut:

Mazhab pertama mengatakan bahwa syariat Islam wajib ditegakkan dan dijadikan sebagai hukum positif. Mazhab ini berpendirian bahwa penggunaan hukum positif selain dengan syariat Islam adalah hal yang diharamkan bahkan menyebabkan muslim masuk keranah kekafiran. Hal ini berdasarkan dalil-dalil berikut ('Audah, 2016: 31-38):

a. Islam melarang umat Islam menjadikan selain hukum Islam dan segala hal yang bertentangan dengan prinsip syariat sebagai hukum positif. Hal ini didasarkan pembagian Allah dalam al-Quran yang mana Allah hanya membagi kelompok menjadi dua golongan, yaitu mereka yang mengikuti Allah dan Rasulnya dan yang kedua golongan yang mengikuti hawa nafsunya. Sebagaimana firman Allah: 


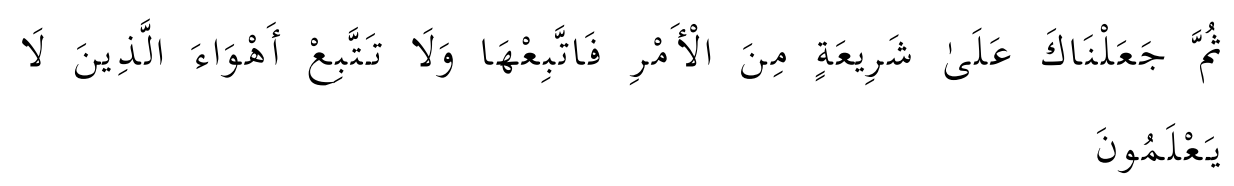

Artinya: "Kemudian Kami jadikan kamu berada di atas suatu syariat (peraturan) dari urusan (agama itu), maka ikutilah syariat itu dan janganlah kamu ikuti hawa nafsu orang-orang yang tidak mengetahui." (QS. Al-Jatsiyah: 18).

b. Allah tidak ridha ketika orang mukmin berhukum dengan selain hukum Allah, bahkan Allah memerintahkan untuk mengingkari semua yang berhukum dengan selain hukum-Nya serta menganggap keridhoan kepada selain hukum Allah adalah kesesatan. Sebagaimana firman-Nya:

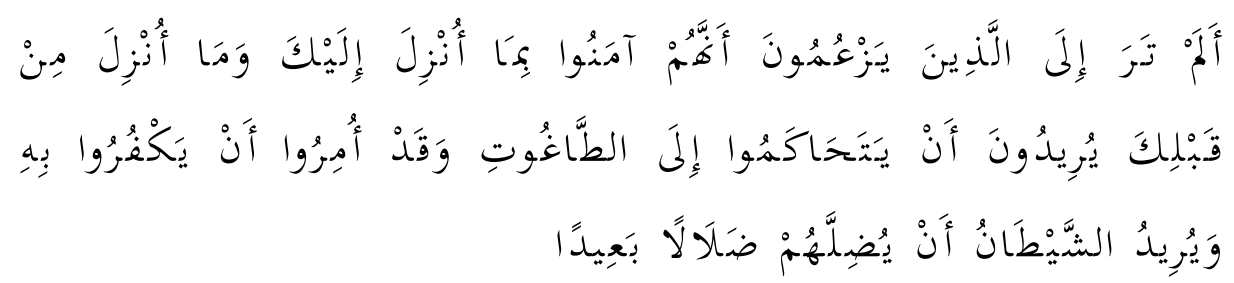

Artinya: "Apakah kamu tidak memperhatikan orang-orang yang mengaku dirinya telah beriman kepada apa yang diturunkan kepadamu dan kepada apa yang diturunkan sebelum kamu? Mereka hendak berhakim kepada thaghut, padahal mereka telah diperintah mengingkari thaghut itu. Dan syaitan bermaksud menyesatkan mereka (dengan) penyesatan yang sejauhjauhnya." (QS. An-Nisa: 60).

c. Allah memerintahkan agar pengambilan keputusan didasari dengan hukum syariat Islam, dan jika tidak mau menggunakannya maka termasuk golongan orang-orang kafir, fasik dan zalim.

d. Dan ayat-ayat lain yang ditafsirkan sebagai dalil pendukung mazhab ini. Antara lain adalah QS. Al-Nisa: 59 dan 65, an-Nisa: 59, serta beberapa hadis nabi misalnya:

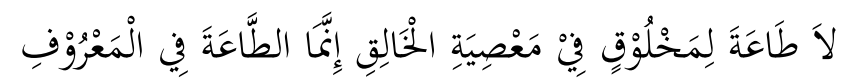

Artinya: "Tidak ada ketaatan kepada makhluk dalam kemaksiatan kepada Sang Pecinpta".

Mazhab kedua merupakan mazhab yang menjadi antitesa mazhab pertama. Mazhab ini mengatakan bahwa menggunakan hukum positif tidaklah masuk ke dalam ranah maksiat kepada Allah Swt., apalagi kafir kepada-Nya. Usamah Sayyid Azhari pemikir asal Mesir dalam bukunya Haqqul Mubìn mengatakan bahwa cara berfikir pejuang Islam syariat pada dasarnya memiliki beberapa kesalahan dalam mengintepretasi ayat al-Quran dan Sunnah (Azhari, 2015: 23), di antaranya adalah sebagai berikut: 
Pemahaman yang salah dari ayat QS. Al-Maidah: 44 yang artinya: "Barangsiapa yang tidak berhukum dengan apa-apa yang diturunkan oleh Allah, maka mereka termasuk orang-orang kafir". Pejuang Islam syariat menafsirkan bahwa mereka yang tidak menggunakan syariat Islam dalam berhukum (meskipun mengakui bahwa hal itu adalah wahyu yang datang dari Allah, hanya saja mereka mempunyai uzur untuk melakukukannya) dimasukan ke dalam golongan kafir. Mereka menjadikan aspek hukum sebagai salah satu syarat keimanan seseorang. Kesimpulan salah tafsir tersebut berujung pada pernyataan bahwa hukum positif adalah hukum yang menyalahi hukum Allah Swt. Mereka beranggapan bahwa penentuan hukum adalah salah satu kekhususan Allah Swt saja, dan manusia tidak boleh membuat hukum. Dengan cara fikir ini kemudian mereka mengkafirkan orang lain yang menggunakan hukum positif. Padahal jika dilihat dalam tafsir-tafsir AlQuran, ayat ini memiliki makna bahwa siapa saja yang mengingkari dalam hatinya dan mengingkari bahwa kalam Allah adalah wahyu yang benar, maka dia adalah kafir, akan tetapi bagi mereka yang memiliki udzur dalam pelaksanaannya maka tidak masuk dalam golongan kafir. Mayortitas ulama tafsir mengamini penafsiran moderat ini seperti misalnya Ibnu Mas'ūd, Ibnu 'Abbās, Ḥudzaifah bin Yaman, Qatādah, Imām Rāzi, Ibnu Katsīr, Qurțūby, Ghazāli, Ibnu 'Āsyur, Imām Sya'rāwi, dan lain sebagainya (Azhari, 2015: 26). Jikapun hendak dirujuk lagi, banyak sekali ulama yang sudah mengkaji dan membolehkan penggunaan hukum positif ini sejak zaman 'Umar yang membentuk beberapa peraturan untuk mengatur negara, lalu kemudian di zaman khiläfah yang juga terjadi perkembangan undang-undang hingga zaman sekarang, yang mana banyak dari undang-udang tersebut tidak dijelaskan dalam AlQuran dan Sunah.

'Ali Jum'ah (mufti Mesir tahun 2010), mengatakan bahwa demokrasi dan apaapa yang ada di dalamnya (termasuk hukum positif) bukanlah berarti pengganti hukum Allah, hal ini dikarenakan keduanya tidak bertentangan. Hukum demokrasi yang ada pada dasarnya sesuai dengan nilai Islam dalam perihal politik, misalnya pemilihan presiden, memerintahkan kepada kebaikan dan mencegah kemunkaran, musyawarah, dan lain-lain (Jum'ah, 2014: 96-98). Hukum positif merupakan sebuah alat untuk mencapai tujuan. Selama alat ini bisa digunakan untuk menuntun kita kepada Allah Swt, maka sah penggunaanya. Penggunaan lafal asing (seperti demokrasi, hukum positif, dan lain sebagainya), yang terkesan tidak "Islami" bukanlah penghalang untuk digunakan, karena pada dasarnya yang penting adalah esensinya, bukan namanya. Oleh karenanya, menggunakan sistem hukum dari negara lain merupakan hal yang sah. Hal ini seperti halnya ketika nabi menggunakan strategi parit saat perang Khandak yang mana strategi itu berasal dari Persia, Umar juga membentuk Undang-undang pada masanya, dan juga penggunaan mata uang dalam masa Umawiyah. 


\section{Kesamaan Pemikiran Mazhab Pertama dengan Paham Khawarij}

Usamah (2015: 45-47) mengatakan bahwa doktrin yang sekarang berkembang, yang mengatakan pengguna hukum positif adalah orang-orang kafir, fasik dan pelaku maksiat pada dasarnya sudah pernah terjadi di zaman para sahabat. Doktrin ini kala itu dipakai oleh orang-orang Khawarij (orang-orang yang keluar dari barisan) ketika mereka menganggap bahwa tahkim (kesepakatan damai) yang dilakukan 'Ali bin Abi Țalib dan Muawiyah kala itu adalah bentuk pengkhianatan terhadap hukum Allah Swt dan memilih menggunakan hukum buatan manusia. Mereka menganggap bahwa penerimaan tahkìm (yang dianggap sebagai hukum buatan manusia) bertentangan dengan QS. Al-Maidah: 44.

Dalam kondisi 'Ali bin Abi Țalib menerima taḥkìm, kaum yang kemudian dinamakan Khawarij ini keluar dari barisan 'Ali bin Abi Talib dan memilih membentuk pasukan sendiri dan memiliki kurang lebih 6000 pengikut. Usamah Azhari (2015: 45) mengutip riwayat panjang mengenai upaya Ibnu 'Abbās dalam menyadarkan kelompok yang keluar barisan tersebut. Ibnu 'Abbās, usai mengetahui ihwal keluarnya sebagian kelompok muslim tersebut, kemudian memutuskan untuk mendatangi tempat pasukan kaum Khawarij dan berusaha untuk menyadarkan mereka dari pemahaman yang salah tentang ayat tersebut. Ibnu 'Abbās bertanya alasan mereka keluar dari kepemimpinan 'Ali. Ada 3 hal yang menjadi alasan: 1) 'Ali telah menjadikan manusia sebagai hakim dalam urusan Allah; 2) Peperangan yang terjadi tidak ada satupun tahanan yang dijadikan tawanan dan tidak muncul kebijakan soal harta rampasan perang; dan 3) 'Ali menghapus kata Amīrul Mu`minīn ketika mengadakan perjanjian. Ketiga alasan tersebut selanjutnya dijawab secara argumentatif oleh Ibnu 'Abbās:

a. Jawaban Alasan Pertama

Ibnu 'Abbās menyampaikan QS. Al-Maidah: 95 sebagai bantahan alasan Khawarij menyelisihi 'Ali. Surat ini menyatakan bahwa Allah menunjukkan kebolehan upaya dalam mengangkat hakim sekaligus penengah dari dua pihak yang berselisih. Ayat 95 dalam QS. Al-Maidah ini turun mengenai penyelesaian perkara harga buruan kelinci yang diperselisihkan antara dua pihak. Proses penyelesaian perkara tersebut selanjutnya diselesaikan oleh manusia yang adil. Ini sebagaimana terjadi pada QS. Al-Nisa: 35 mengenai penunjukan seoarang mediator (hakaman) dari dua belah pihak yang menengahi perselisihan antara suami dan isteri.

b. Jawaban Alasan Kedua

Alasan Khawarij terkait dengan tidak adanya tawanan perang dan harta rampasan perang pada peperangan yang terjadi bersama 'Ali dijawab dengan QS. Al-Ahzab: 6. Ayat ini menjelaskan bahwa Nabi adalah seorang yang utama bagi orang-orang yang beriman dan isteri-isterinya merupakan ibu-ibu bagi orang-orang mukmin. Konteks perang yang dimaksud adalah pertikaian antara 'Ali dengan 'Aisyah yang masyhur 
disebut dengan Perang Jamal (Perang Unta). Ibnu 'Abbās menyatakan bahwa jika Khawarij mengingkari bahwa 'Aisyah adalah ibu dari mereka (berdasarkan ayat tersebut) maka sejatinya Khawarij telah kafir. Jika pengakuan 'Aisyah sebagai isteri dan ibu dari orang-orang mukmin nyata, maka tidaklah mungkin seorang Ibu tega ditawan oleh anak-anaknya. Pada posisi inilah sebenarnya 'Ali berada pada posisi kepemimpinan yang benar.

c. Jawaban Alasan Ketiga

Dihapuskannya gelar Amīrul Mu`minīn ketika terjadi perjanjian adalah upaya diplomatis yang pernah dilakukan oleh Rasulullah Saw pada saat Perjanjian Hudaibiyah. Rasulullah Saw pada perjanjian tersebut menghapus gelarnya secara tertulis sebagai Rasul, beliau hanya menulis, "perjanjian damai antara Muhammad bin Abdullah dan Suhail bin 'Amr. Tidak dituliskannya gelar tersebut bukan berarti gelar yang telah tersandang menjadi hilang begitu saja.

Dari riwayat sejarah yang panjang ini dapat diambil kesimpulan bahwa pemikiran mazhab pertama yang sampai mengkafirkan pengguna hukum positif dengan dalil Al-Quran, pada dasarnya sudah menyalahi Al-Quran itu sendiri. Ibnu 'Abbās dalam hal ini merupakan ahli tafsir di kalangan para sahabat yang dikaruniai kemampuan tafsir yang sangat mendalam, apalagi jika dibandingkan dengan kaum Khawarij yang Al-Quran saja tidak turun kepada mereka. Kemampuan tafsir Ibnu 'Abbās juga didasari dengan hadis nabi "Ya Allah, berilah dia pemahaman dalam masalah agama dan ajarkanlah kepadanya tafsir."

\section{Penerapan Hukum Islam di Indonesia}

Jika dilihat dengan teori hubungan agama dan negara, Indonesia merupakan negara yang menganut faham paradigma simbolistik. Mau tidak mau Indonesia harus mengakomodir perkembangan pemikiran yang mencoba untuk memasukan nilai-nilai hukum Islam kedalam hukum positifnya. Indonesia tidak boleh menolak mentah-mentah ketika dalam perkembanganya terdapat tuntutan mensyariahkan hukum positif. Meskipun begitu, pemasukan nilai syariah ke dalam hukum positif juga harus dilakukan dengan cara yang diamini oleh bangsa ini, yaitu sesuai dengan keilmuan dalam disiplin ilmu hukum dan sesuai dengan proses demokrasi, bukan indoktrinasi (Mu'allim, 2013: 2).

Hukum Islam yang berlaku di Indonesia, pada dasarnya ada dua, yaitu hukum Islam yang berlaku secara normatif dan yang berlaku secara yuridis. Hukum Islam yang menyangkut hubungan antara manusia dengan tuhan pada dasarnya adalah normatif yang sanksinya adalah sanksi kemasyarakatan. Sedangkan yang bersifat yuridis adalah yang mengatur hubungan manusia dengan manusia dan benda di dalam masyarakat, yang mana Indonesia sudah mengakomodir hal ini dalam beberapa Undang-Undangnya. Hukum Islam sebelum dipositifkan, pada dasarnya termasuk dalam kategori living law (labendes recht/hukum yang hidup), yaitu 
hukum yang secara umum digunakan untuk mencegah munculnya perkara dan apabila muncul perkara, hukum tersebut digunakan untuk menyelesaikan perkara tersebut tanpa bantuan saran institusi hukum negara (Cotterral, 2012: 38). Jadi tanpa dipositifkan sekalipun, sebenarnya hukum Islam sudah diterima oleh masyarakat Indonesia secara luas tanpa paksaan dari pihak berkuasa. Sehingga langkah pemerintah mengakomodir hukum ini sebagai hukum positif agar dapat sah secara administrasi negara tentu juga merupakan hal yang tepat dan dapat diterima oleh umum.

Sebagai contoh bahwa Indonesia telah mengakomodir hukum Islam adalah beberapa peraturan berikut (Mu'allim, 2013: 3):

a. Sila pertama Pancasila: Ketuhanan yang Maha Esa. Sila ini merupakan landasan bagi sila-sila yang lain dan juga seluruh aturan undang-undang yang berlaku di Indonesia. Sehingga seluruh aturan yang ada tidak boleh melenceng dari norma agama.

b. Pasal 29 ayat 1: Negara berdasar atas Ketuhanan yang Maha Esa.

c. Keputusan Uji Materi MK tentang UU PNPS Nomor 1 tahun 1965 tentang pencegahan, penyalahgunaan, dan/ atau penodaan agama. MK menandaskan, Indonesia adalah bangsa yang bertuhan, bukan bangsa yang atheis.

d. Impres No. 1 tahun 1991 tentang Kompilasi Hukum Islam.

e. UU No. 1 tahun 1974 tentang Perkawinan.

f. UU No. 3 tahun 2006 tentang Perubahan UU No. 7 tahun 1989 tentang PA.

g. UU No. 38 tahun 1999 tentang Pengelolaan Zakat.

h. UU No. 20 tahun 2003 tentang pasal 20 tentang pendidikan agama.

i. UU No 41 tahun 2004 tentang Wakaf.

j. UU No. 21 tahun 2008 tentang Perbankan Syariah.

k. UU No. 13 tahun 2008 tentang Penyelenggaran Ibadah Haji.

l. UU No. 19 tahun 2008 tentang Surat Berharga Syariah Negara.

m. UU No. 21 tahun 2008 tentang Perbankan Syariah.

Realita perjuangan penegakan syariah Islam di Indonesia sudah digambarkan di banyak penelitian, salah satunya dalam Islam Syariat yang sebelum menjadi buku, merupakan disertasi karya Haedar Nashir. Perjuangan ini, dapat dilihat dengan jelas dengan adanya kelompok-kelompok bernafaskan Islam baik itu organisasi, pergerakan, maupun partai yang kemudian mengusung gerakan penegakan syariah Islam sebagai hukum positif. Dalam bukunya, Haedar Nashir (Nashir, 2013: 386293) membagi kelompok ini dalam dua golongan, yaitu:

a. Golongan Islamisasi jalur bawah (bottom-up) yaitu mereka yang menerapan syariat Islam di daerah-daerah melalui peraturan-peraturan daerah, instruksi Bupati, dan instrumen lainnya. Contohnya adalah pergerakan syariat Islam di Sulawesi Selatan, NAD, Jawa Barat, dan beberapa daerah lainnya yang memiliki tipologi yang sama. 
b. Golongan Islamisasi jalur atas (top-down), yaitu mereka yang menggunakan jalur dari atas ke bawah, maksudnya adalah proses penegakan Islam syariat dilakukan melaui kekuasaan negara sebagai suatu aktivisme politik. Misal dari golongan ini adalah seperti HTI (Hizbut Tahrir Indonesia) yang menuntut untuk menegakkan khilafah Islamiyah dan penegakan syariat, MMI (Majelis Mujahidin Indonesia) yang cenderung dengan tuntutan penerapan syariat Islam dan memperjuangkan Piagam Jakarta. Tidak hanya dua organisasi tersebut, akan tetapi juga partai-partai yang memperjuangkan kembalinya piagam Jakarta ke dalam konstitusi juga masuk dalam kategori ini, antara lain: PPP, PBB, PKS. FPI.

Terlepas dari perdebatan mengenai perbedaan pendapat mengenai penggunaan hukum positif yang berujung pada bagaimana konsep negara yang baik dan benar menurut pandangan masing-masing sarjana muslim, Indonesia adalah negara yang majemuk dengan tingkat pluralitas yang sangat tinggi. Pemaksaan terhadap salah satu paham ideologi sebagai ideologi negara yang cenderung tidak mengakomodir paham lainnya, hanya akan membuat negara dan masyarakatnya menjadi korban. Jamak diketahui bahwa revolusi (termasuk salah satunya perubahan paham negara) hampir pasti diwarnai dengan warna darah. Dalam sejarah Islam kita bisa mengambil contoh fitnah yang terjadi antara pasukan Ali dan Muawwiyah, perebutan kekuasaan antara bani Abbasiyah dan bani Ummayah, runtuhnya Khilafah Utsmaniyah, revolusi Iran, dan lain-lain.

Islam sendiri secara konseptual, memiliki tujuan menjadi agama yang raḥmatan lil 'ālamīn. Maka akan menjadi absurd jika pemaksaan paham (Islam sebagai misal), justru akan memperbanyak pertumpahan darah, ketidak stabilan ekonomi, politik, dan sosial. Dalam pandangan penulis, hukum apapun dan juga konsep negara apapun itu, pada dasarnya hanyalah sebuah cara/metode untuk menuju sebuah tujuan. Islam sendiri dalam bernegara memiliki tujuan untuk menjadikan sebuah negara yang baldatun țayyibatun wa rabbun ghafür (negara yang baik dan dalam ampunan Allah) sebagaimana dalam surat QS. Al-Saba: 15, yang penduduknya beriman dan bertakwa sehingga diberkahi Allah sebagaimana dalam QS Al-A'raf; 96, dan membangun negeri tersebut dengan sebaik-baiknya dan tidak merusak sebagaimana dalam QS Al-Baqarah: 11, 60; QS. Al-Rum: 41; dan QS. AlQashas: 77. Oleh karena itu, ijtihad dalam menentukan sebuah sistem (metode) kebangsaan seharusnya tidak boleh mengorbankan tujuan yang sudah jelas, apalagi metode tersebut pada dasarnya masih bisa kita dinegosiasikan dan disepakati bersama.

Dalam konteks ke-Indonesia-an, daripada harus memaksakan ideologi Islam sebagai paham negara, Pancasila merupakan metode yang tepat untuk meraih tujuan Islam sebagai agama yang rahmatan lil 'alamin. Ideologi Pancasila bisa dikatakan merupakan kesepakatan cerdas para founding-father kala itu, karena 
dengan hal ini, Indonesia terbebas dari perpecahan bahkan pertumpahan darah, sekaligus tetap bisa mewujudkan cita-cita Islam sebagai agama raḥmatan lil 'ālamìn.

NU dan Muhammadiyah sebagai ormas Islam terbesar di Indonesia-pun mengakui Pancasila sebagai falsafah negara. Bagaimanapun juga, beberapa anggota BPUPKI adalah ulama dari kedua ormas Islam ini, sehingga secara langsung bisa dipastikan keduanya menerima Pancasila sebagai dasar hukum yang berlaku di Indonesia. Konsep Negara Pancasila semakin ditekankan oleh NU dalam Munas Alim Ulama NU di Situbondo pada tahun 1983. Muhammdiyah sendiri, menekankan sikap atas Negara Pancasila dalam Muktamar Muhammdiyah ke 47 di Makasar pada tahun 2015. Dalam muktamar tersebut, Muhammadiyah mengkategorikan Negara Pancasila sebagai Dārul 'ahdi Wa Syahādah. Maksudnya yaitu Negara Pancasila adalah negara hasil konsensus nasional (dār al-'ahdi), dan juga negara tempat pembuktian dan kesaksian (dār asy-syahādah) untuk menjadi negeri yang damai (dār al-salām), menuju kehidupan yang adil, makmur, bermartabat dan diridlai oleh Allah Swt (Pimpinan Pusat Muhammadiyah, 2015: 12).

Selain itu, pada dasarnya ideologi negara Islam-pun (dan bahkan semua ideologi), tidak akan bisa menjamin sebuah negara akan makmur, adil, aman sentosa. Sejarah mencatat, bahwa tidak semua kekhalifahan Islam berjalan dengan mulus, adil, dan bahkan justru jauh dari kata rạmmatan lil 'àlamīn. Ambil contoh Khalifah al-Amīn Muhammad Abū 'Abdullāh bin Rasyīd yang mewarisi tahta dari keberhasilan bapaknya Hārun Al-Rasyīd yang memimpin pada tahun 193-198 H. Imām Suyūṭi dalam kitabnya Tārikh Khulafā menggambarkannya sebagai perancang yang buruk, boros, memiliki akal yang lemah, bodoh, dan tidak cakap sebagai khalifah. Bahkan pertama kali yang dia lakukan setelah dua hari dibaiat sebagai khilafah adalah membuat lapangan bola di samping istana al-Mansur untuk bermain bola. Dia juga menggeser Al-Ma'mūn yang merupakan calon raja (Wali al-'ahdi) setelahnya atas wasiat dari Hārun Al-Rasyīd dan kemudian memberikan gelar wali al'-ahdi itu kepada anaknya sendiri yang bernama Mūsa yang kala itu masih menyusu. Al-Amīn yang memberi gelar anaknya sebagai Al-Nāțiq bil ḥaq (Penyuara Kebeneran) bahkan kemudian mengambil surat wasiat ayahnya yang ada di Kakbah yang menyatakan bahwa Al-Ma'mūn adalah wali al-'ahdi (raja setelah al-Amīn), dan merobek surat wasiat tersebut (Suyūți: 219).

Cerita ini baru satu dari sederetan kekejaman khalifah Islam lainya. Jika pendukung konsep khilafah mau jujur pada sejarahnya sendiri, masih ada sederetan khalifah seperti al-Ma'mūn, Mu'tashim, al-Wātsiq yang mengkriminalisasi para ulama sekelas Imām Aḥmad bin Hanbal hingga dicambuk dan dipenjara hanya karena berbeda paham, dan cerita-cerita kelam lainnya. Secara gamblang penulis dapat menyatakan bahwa penerapan negara Islam di Indonesia tidak dapat menjadi jaminan bahwa tujuan Islam sebagai agama rạ̣matan lil 'ālamìn akan tercapai, alihalih justru bisa menjadi bumerang yang merusak citra agama Islam sendiri jika pemimpin yang didapati bergaya seperti al-Amīn. 
Sebagai bukti nyata di era kekinian, negara yang berafiliasi dengan agama Islam baik karena deklarasi dalam UU-nya (Iran, Saudi, dan Paskistan), ataupun karena banyaknya muslim di negara tersebut (Indonesia, Malaysia, dan lain sebagainya), belum mampu memberikan kepercayaan kepada publik sebagai negara yang maju dan sejahtera. Dalam sebuah penelitian oleh Cheherazade S Rehman dan Hossein Askari dari The George Washington University yang dipublikasikan dalam Global Economy Journal (dipublikasikan tahun 2010), mereka menyatakan bahwa Selandia Baru merupakan negara paling Islami disusul oleh Luksemburg. Dari 208 negara yang diikutsertakan dalam penilaian dari 56 negara anggota OKI (Organisasi Kerjasama Islam), yang memperoleh nilai tertinggi adalah Malaysia (urutan ke-38), Kuwait (48), Uni Emirat Arab (66), Maroko (119), Arab Saudi (131), Indonesia (140), Pakistan (147), Yaman (198), dan terburuk adalah Somalia (206). Justru Negara Barat, mendapat peringkat yang bagus dan dinilai mendekati nilai-nilai Islam, sepeti Kanada di urutan ke-7, Inggris (8), Australia (9), dan Amerika Serikat (25). Dari sini terlihat, bahwa negara Islam yang merupakan anggota OKI-pun tidak ada yang masuk 30 besar. Perlu diketahui bahwasanya, aspek yang dijadikan parameter dalam penelitian ini adalah nilai-nilai Islam (dan bukan dalam hal peribadatan). Parameter itu adalah, pertama, ajaran Islam mengenai hubungan seseorang dengan Tuhan dan hubungan sesama manusia. Kedua, sistem ekonomi dan prinsip keadilan dalam politik serta kehidupan sosial. Ketiga, sistem perundangundangan dan pemerintahan. Keempat, hak asasi manusia dan hak politik. Kelima, ajaran Islam berkaitan dengan hubungan internasional dan masyarakat non-Muslim (http://nasional.kompas.com/read/2011/11/05/02042887/keIslaman.indonesia, diunduh pada hari Selasa, 28 November 2017).

Meskipun begitu, positifisasi hukum Islam menjadi hukum negara merupakan hal yang diperlukan, mengingat bahwa mayoritas penduduk Indonesia adalah muslim. Hukum Islam dalam hal ini, bisa dan mampu untuk hidup berdampingan dengan hukum yang sudah ada di negara Indonesia, baik hukum adat maupun hukum ala Eropa Kontinental. Meskipun perkembangan positifisasi hukum Islam dinilai kurang memuaskan karena selama 72 tahun merdeka baru segelintir aspek yang dipositifkan, akan tetapi tren menunjukan bahwa Indonesia tetap melangkah maju dalam hal ini. Sebagai contoh, perkembangan peraturan mengenai Ekonomi Islam yang dimulai dengan pengesahan UU No 7 tahun 1992 tentang Perbankan, yang kemudian muncul banyak regulasi berkaitan dengan hal ini seiring kebutuhan masyarakat akan hal tersebut, termasuk salah satunya UU No 28 tahun 2008 tentang Perbankan Syariah, dan masih banyak contoh lainya. Ke depan, tentunya kita berharap bahwa regulasi-regulasi syariah yang ada, dapat disahkan, dan lebih dari itu, kemudian bisa bermanfaat dan bisa menunjukan Islam sebagai agama yang raḥmatan lil 'âlamìn. 


\section{KESIMPULAN}

Dari tulisan ini setidaknya kita dapat mengambil kesimpulan bahwa dilihat dari jenis hubungan antara negara dan agama di Indonesia bukanlah termasuk ke dalam kategori negara agama (teokrasi). Agama dan negara di Indonesia memiliki hubungan simbiotik di mana keduanya saling mempengaruhi dan saling membutuhkan. Agama dijadikan sebagais alah satu nilai dasar dalam pembentukan peraturan di Indonesia, dan negara menjamin kebebasan beragama untuk menuju negara yang lebih baik. Mengkategorikan Indonesia adalah negara țāghūt hanya karena tidak menjadikan Al-Quran dan Sunah sebagai landasan dasar negara merupakan suatu pemikiran yang salah kaprah. Karena jika kita menggunakan logika sesederhana itu, ISIS (terlepas setuju atau tidak dengan ISIS) akan termasuk ke dalam kategori negara Islam.

Negara Islam (yang tidak țāghūt) tidak bisa jika hanya dinilai dari landasannya saja. Indonesia dalam hal ini, meskipun tidak secara resmi menggunakan Syariat Islam, tetap membolehkan Syariat Islam untuk digunakan, bahkan dijadikan peraturan resmi negara. Masalahnya tinggal umat Islam mampu atau tidak dalam mempositifisasikan Syariat Islam. Jangan sampai kita menyalahkan sistem padahal kitanya yang tidak mampu. Hal ini seperti kita menyalahkan senapan karena kita tidak bisa menembak.

Pancasila sebagai dasar negara justru sangat sesuai dengan nilai-nilai Islam. Bahkan semua sila yang ada di dalam Pancasila memiliki sumberunyadalam AlQuran. Di sisi lain, model kekhilafahan Islam sendiri dari zaman Nabi Muhammad hingga Dinasti Utsmaniyah runtuh, juga memiliki model yang berebeda-beda. Mulai dari Nabi yang menunjuk langsung penggantinya, kemudian Utsmān dan 'Ali bin Abi Țālib yang dipilih lewat voting seperti halnya model parlementer, serta model kerajaan yang mana pemimpin dipilih berdasarkan keturunan. Dari sini kemudian penulis sendiri berkesimpulan dan berhipotesis bahwa jika Pancasila bisa benarbenar ditegakkan (bukan hanya sebagai alat kekuasaan) dan kemudian tujuannya bisa tercapa, maka Pancasila bisa dikatakan masuk ke dalam kategori model sistem khilafah.

\section{DAFTAR PUSTAKA}

'Audah, Abdul Qādir (2016). Pertarungan antara Hukum Isam dan Hukum Positif. Yogyakarta: Kaukaba Dipantara.

Azhari, Usamah (2015). Haqqul Mubīn, Abu Dhabi: Dār Al-Faqīh.

Cotterral, Roger (2012). Pengantar Sosiologi Hukum, Terjemah: Narulita Yusron, Bandung: Nusa Media.

Esnawi, Eddy (2013). Islam \& Negara, Yogyakarta: Fahma Media.

Haedar Nashir (2013). Islam Syariat: Reproduksi Salafiyah Ideologis di Indonesia, Bandung: Mizan Media Utama.

Jum'ah, Ali (2014). Al-Bayān limā Yusghilu al-Adzhān, Cairo: Dār Al-Muqaț̣tom. 
Khalaf, Abdul Wahab (2003). 'Ilmu Al-Ușūl Al-Fiqh, Cairo: Dār Al-Ḥadīts.

Marzuki, Peter Mahmud (2014). Pengantar Ilmu Hukum, Jakarta: Kencana.

Mertokusumo, Sudikno (2007). Mengenal Hukum: Suatu Pengantar, Yogyakarta: Liberty.

Mu'allim, Amir (2013). Dinamika Hukum Islam di Indonesia, Yogyakarta: Kaukaba Dipantara.

Pimpinan Pusat Muhammadiyah (2015). Negara Pancasila Sebagai Darul 'Ahdi Wa Syahadah. Yogyakarta: Suara Muhammadiyah.

Suyuthi (911 H). Tārīkh Khulafā, Maktabah Nizār Mușțofa Al-Baz.

http://nasional.kompas.com/read/2011/11/05/02042887/keislaman.indonesia 